medRxiv preprint doi: https://doi.org/10.1101/2021.06.10.21258715; this version posted June 16, 2021. The copyright holder for this preprint (which was not certified by peer review) is the author/funder, who has granted medRxiv a license to display the preprint in perpetuity.

It is made available under a CC-BY-NC-ND 4.0 International license .

- Manuscript type: Research Article

\title{
Title page \\ Role of Hemogram-Derived Ratios and Systemic-Immune Inflammation Index in Prediction of COVID-19 Progression in Egyptian Patients
}

Running title: Hemogram Ratios in COVID-19 Progression.

\author{
Authors: \\ Sara I. Taha ${ }^{a *}$, Sara F. Samaan ${ }^{b}$, Shereen A. Baioumy ${ }^{c}$, Aalaa K. Shata ${ }^{d}$, Mariam K. \\ Youssef $^{a}$
}

a. Department of Clinical Pathology, Faculty of Medicine, Ain-Shams University, Cairo, Egypt.

b. Department of Internal Medicine, Faculty of Medicine, Ain-Shams University, Cairo, Egypt.

c. Department of Microbiology and Immunology, Faculty of Medicine, Zagazig University, Zagazig, Egypt.

d. Department of Pulmonary Medicine, Faculty of Medicine, Ain Shams university, Cairo, Egypt.

\section{Authors:}

Sara Ibrahim Taha*

Degree: MD Clinical Pathology/Immunology

Lecturer of Clinical Pathology/ Immunology, Faculty of Medicine, Ain Shams University, Cairo, Egypt.

E-mail: $\underline{\text { dr_sara_ib@med.asu.edu.eg }}$

\section{Sara Farid Samaan}

Degree: MD Internal Medicine

Lecturer of Internal Medicine, Faculty of Medicine, Ain Shams university, Cairo, Egypt.

E-mail: Dr.sara_farid@yahoo.com

\section{Shereen Atef Baioumy}

Degree: MD Microbiology and Immunology

Lecturer of Microbiology and Immunology, Zagazig University, Zagazig, Egypt.

Email: drshereenatef@yahoo.com

\section{Aalaa Kamal Shata}

Degree: MD Pulmonary medicine

Lecturer of Pulmonary Medicine, Faculty of Medicine, Ain Shams university, Cairo, Egypt.

E-mail: aalaashata@yahoo.com

\section{Mariam Karam Youssef}

Degree: MD Clinical Pathology/Hematology

Lecturer of Clinical Pathology/Hematology, Faculty of Medicine, Ain-Shams University, Cairo, Egypt.

E-mail: Dr.mariam_karam@ hotmail.com

\section{* Corresponding Author:}

Sara Ibrahim Taha, MD, PhD

Lecturer of Clinical Pathology/ Immunology, Faculty of Medicine, Ain Shams University.

Address: Ain Shams University, Abassia, Cairo, Egypt

Office tel., fax: + (202) $24346308 \quad$ Mobile: + (20) 1125360009

E-mail: dr_sara_ib@med.asu.edu.eg

https://orcid.org/0000-0001-8224-8701 
medRxiv preprint doi: https://doi.org/10.1101/2021.06.10.21258715; this version posted June 16, 2021. The copyright holder for this preprint (which was not certified by peer review) is the author/funder, who has granted medRxiv a license to display the preprint in perpetuity.

It is made available under a CC-BY-NC-ND 4.0 International license .

1

2

\section{$\underline{\text { Abstract }}$}

Background: Early detection of COVID-19 patients with potentially severe disease is

crucial for predicting the disease's course and prioritizing medical resources, lowering overall disease mortality. Objectives: To explore the role of hemogram-derived ratios and systemic-immune inflammation index (SII), in addition to C-reactive protein (CRP), in predicting COVID-19 severity and prognosis. Methods: In this retrospective study, data were collected from the medical records of 425 COVID-19 patients. Neutrophil-tolymphocyte ratio (NLR), platelet-to-lymphocyte ratio (PLR), and SII, together with the CRP, were investigated and compared. Results: NLR, PLR, SII, and CRP increased significantly in severe cases and with ICU admission $(\mathrm{p} \leq 0.001)$. But, in non-survivors only NLR and CRP were significantly elevated $(\mathrm{p}<0.05)$. By interpreting area under the receiver operating characteristic curve (ROC-AUC), CRP and NLR were better predictors of disease severity (AUC: 0.7 for both), the need for ICU admission (AUC: 0.763 and 0.727 , respectively) and in-hospital mortality (AUC: 0.812 and 0.75, respectively). SII was significantly associated with the risk of severe disease development (odds ratio (OR): 3.143; 95\% confidence interval (CI): 1.101-8.976); CRP (OR: 2.902; CI95\%: 1.342-6.273) and NLR (OR: 2.662; CI95\%, 1.072-6.611) were significantly associated with ICU admission risk; and only CRP was significantly associated with inhospital mortality risk (OR: 3.988; CI95\%: 1.460-10.892). Conclusions: Values of CRP, SII, and NLR at the time of hospital admission could be independent prognostic biomarkers to predict COVID-19 progression. The integration of CRP, SII, and NLR into prognostic nomograms may lead to improved prediction.

Keywords: Coronavirus; Inflammation index; Lymphocyte ratio; Mortality; Progression. 
medRxiv preprint doi: https://doi.org/10.1101/2021.06.10.21258715; this version posted June 16, 2021. The copyright holder for this preprint (which was not certified by peer review) is the author/funder, who has granted medRxiv a license to display the preprint in perpetuity.

It is made available under a CC-BY-NC-ND 4.0 International license .

\section{INTRODUCTION:}

Fatal coronavirus, named severe acute respiratory syndrome coronavirus-2 (SARS-CoV2), has caused novel corona virus disease (COVID-19) which first broke out in December 2019 in Wuhan, China [1]. Fever, dry cough, and fatigue are the main manifestations of COVID-19. In more severe cases, patients often have dyspnea and/or hypoxemia that can rapidly progress to acute respiratory distress syndrome, septic shock, metabolic acidosis, coagulation dysfunction, and multiple organ failure [2].

Although the majority of COVID-19 patients have been classified as mild cases that can recover shortly after appropriate clinical intervention, rapid severe progression of the disease can occur with increasing rates of hospitalization, ICU admission and mortality [3]. Furthermore, not all COVID-19 patients have symptoms in the early stage of the disease, making early tracking of suspected cases very important [4]. Neither the detection capability of viral nucleic acid kits nor the popular rate of pulmonary imaging can support large-scale screening of all populations. In the current novel corona virus pandemic, if the most routine and inexpensive peripheral blood tests have characteristic changes for infected patients, especially those with severe infections, they will be very helpful for proper early clinical intervention to reduce the mortality of patients. Complete blood count $(\mathrm{CBC})$ is the most widely performed, cost effective test that can be performed in almost all laboratories, even in those with limited equipment [4].

In this study, the role of peripheral CBC derived biomarkers (NLR, PLR, SII) together with the CRP at hospital admission, has been examined to predict the progression and the outcome of COVID-19 infection in a cohort of Egyptian patients. 
medRxiv preprint doi: https://doi.org/10.1101/2021.06.10.21258715; this version posted June 16, 2021. The copyright holder for this preprint (which was not certified by peer review) is the author/funder, who has granted medRxiv a license to display the preprint in perpetuity.

It is made available under a CC-BY-NC-ND 4.0 International license .

\section{MATERIALS AND METHODS}

\section{$48 \quad$ Patient selection:}

49 This retrospective study was conducted in line with research regulations, including the

50 approval of Ain-Shams University Faculty of Medicine Research Ethics Committee

51 (REC). Data were acquired anonymously from hospital records and kept private and

52 confidential. They were only used for study purposes.

53 We randomly selected 425 COVID-19 patients admitted to Quarantine Hospitals of Ain-

54 Shams University (El-Obour Ain Shams University Specialized Hospital and El-

55 demerdash Hospital), Cairo, Egypt, between February and April, 2021. COVID-19

56 infection was confirmed in all cases by a positive reverse transcription polymerase chain

57 reaction (RT-PCR) test result for nasal and pharyngeal swab specimens. Only patients

58 above the age of 18 years were included in the study. The study excluded pregnant

59 women and patients with aplastic anemia, lymphoproliferative or myeloproliferative

60 disorders, immune deficiency, and a history of taking drugs that affect blood cell counts

61 such as epinephrine, thyroxin, or corticosteroids.

\section{Data collection:}

63 Demographic and clinical data were collected from the medical records of the patients,

64 including: age, gender, clinical presentation, detailed medical and drug history, presence

65 of co-morbidities, need for ICU admission and patients' outcome. Also, on admission,

66 laboratory findings were collected and analyzed, including $\mathrm{CBC}$ with differential counts

67 and CRP. Blood cell ratios and indexes of systemic inflammation were calculated, 
medRxiv preprint doi: https://doi.org/10.1101/2021.06.10.21258715; this version posted June 16, 2021. The copyright holder for this preprint (which was not certified by peer review) is the author/funder, who has granted medRxiv a license to display the preprint in perpetuity.

It is made available under a CC-BY-NC-ND 4.0 International license .

68 including: the NLR (neutrophil/lymphocyte ratio), PLR (platelet/lymphocyte ratio) and

69 SII ((neutrophils $\times$ platelets $) /$ lymphocytes $)$.

70 Categorization of patients was done in accordance with guidelines of Ain Shams

71 University Hospitals Consensus Statement on Management of Adult COVID-19 Patients

$72[5]$.

\section{Statistical analysis:}

74 Categorical variables were analyzed using the Chi-square test and were expressed as a

75 number and percentage. For analysis of the parametric variables, the independent samples

76 t-test was used and they were presented as a mean and standard deviation. Non-

77 parametric variables were analyzed by the Mann-Whitney $U$ test and presented as the

78 median and interquartile range (IQR). The ROC curve analysis was used to assess the

79 predictive performance of the significant parameters. To analyze the association between

80 the COVID-19 severity, need for ICU admission or in-hospital mortality, and related

81 factors, univariate and multivariate analyses were carried out using a logistic regression

82 model. The statistical analysis of the data was performed using SPSS version 20.0

83 software. A p value of $\leq 0.05$ was considered statistically significant.

\section{$84 \quad$ RESULTS}

\section{Demographic and cinical characteristics of the entire study cohort:}

86 A total of 425 adult patients (227 females and 198 males) with confirmed COVID-19

87 infection were included in this study. Of them, 188 (44.2\%) patients were mild, while 237

$88(55.8 \%)$ were moderate/severe cases. The mean age was $47.90 \pm 17.08$ years.

89 Hypertension (34.1\%) and diabetes (30.4\%) were the most common co-morbidities. Only 
medRxiv preprint doi: https://doi.org/10.1101/2021.06.10.21258715; this version posted June 16, 2021. The copyright holder for this preprint (which was not certified by peer review) is the author/funder, who has granted medRxiv a license to display the preprint in perpetuity.

It is made available under a CC-BY-NC-ND 4.0 International license .

$90112(26.4 \%)$ patients required ICU admission. Of all studied subjects, $385(90.6 \%)$

91 patients were discharged alive, whereas the remaining $40(9.4 \%)$ died. The median

92 hospitalization duration was 10 days (IQR: $6-17$ ). The baseline characteristics of the

93 included patients are shown in tables 1 (a) and 2 (a).

94 Clinical variables associated with disease severity:

95 Table 1 (b) summarizes the characteristics of the mild $(n=188)$ and moderate/severe $(n$ $96=237)$ groups. The mean age of the moderate/severe group was significantly higher than

97 that of the mild group (53.47 years \pm 16.10 vs. 40.84 years \pm 15.65 ; $p<0.05$ ), with no

98 statistically significant difference in gender between both groups $(\mathrm{p}>0.05)$. Of the

99 moderate/severe group, $108(45.6 \%)$ patients required ICU admission and 40 (16.9\%)

100 patients died. In contrast, of the mild group, only $4(2.1 \%)$ patients required ICU

101 admission and no deaths occurred. The moderate/severe group had a statistically

102 significant longer length of hospital stay when compared to the mild group (14 days

103 (IQR: 9 - 20) vs 7 days (IQR: $5-10), \mathrm{p} \leq 0.001$ ).

104 Table 2 (b) shows that co-morbidities including chronic obstructive pulmonary disease

105 (COPD), diabetes mellitus, hypertension, chronic liver disease, chronic kidney disease

106 and ischemic heart disease were significantly associated with disease severity $(\mathrm{P} \leq 0.001)$

107 The moderate/severe group had statistically significant lower hemoglobin and 108 lymphocyte count but statistically significant higher total leukocytic count (TLC), PLR,

109 NLR, SII and CRP when compared to the mild group $(\mathrm{P}<0.05)$. Platelet and neutrophil 110 counts were not significantly different between groups ( $p>0.05)$. Table 3 (b)

\section{Clinical variables associated with ICU admission:}


medRxiv preprint doi: https://doi.org/10.1101/2021.06.10.21258715; this version posted June 16, 2021. The copyright holder for this preprint (which was not certified by peer review) is the author/funder, who has granted medRxiv a license to display the preprint in perpetuity.

It is made available under a CC-BY-NC-ND 4.0 International license .

112 The mean age of the ICU group $(n=112)$ was significantly higher than that of the non-

113 ICU group $(\mathrm{n}=313)(56.83$ years \pm 15.75 vs. 44.70 years $\pm 16.41 ; \mathrm{p} \leq 0.001)$, but no

114 statistically significant difference in gender was found between the groups $(\mathrm{p}>0.05)$.

115 The ICU group had a statistically significant longer length of hospital stay when

116 compared to the non-ICU group (19 days (IQR: 9 - 22) vs 9 days (IQR: $6-13$ ), $\mathrm{p} \leq$

117 0.001). Of the ICU group, 108 (96.4\%) patients were moderate/severe and 4 (3.6\%)

118 patients were mild. Only 39 (34.8\%) patients of the ICU group died. Table 1 (c)

119 All the previously mentioned co-morbidities were significantly associated with ICU 120 admission $(\mathrm{P} \leq 0.001)$ except chronic liver disease $(\mathrm{p}>0.05)$. Table 2 (c)

121 Similar to the moderate/severe group, the ICU group had statistically significant lower

122 hemoglobin and lymphocyte count but statistically significant higher TLC, PLR, NLR,

123 SII and CRP when compared to the non-ICU group $(\mathrm{P} \leq 0.001)$. Platelet and neutrophil

124 counts were not significantly different between groups $(\mathrm{p}>0.05)$. Table 3 (c)

\section{Clinical variables associated with in-hospital mortality:}

126 Table 1 (d) summarizes the demographic and clinical characteristics for survivors

$127(n=385)$ and non-survivors $(n=40)$. Non-survivors were significantly older than survivors

128 (mean age: 60.30 years \pm 13.60 vs. 46.61years $\pm 16.90 ; \mathrm{p} \leq 0.001$ ) with no significant

129 gender difference. They had a statistically significant longer length of hospital stay when

130 compared to survivors (18 days (IQR: $7-22)$ vs 10 days (IQR: $6-15), \mathrm{p}<0.05)$.

131 Table 2 (d) shows that chronic liver disease was not significantly associated with in-

132 hospital mortality $(\mathrm{p}>0.05)$ but the other mentioned comorbidities did $(\mathrm{p}<0.05)$. 
medRxiv preprint doi: https://doi.org/10.1101/2021.06.10.21258715; this version posted June 16, 2021. The copyright holder for this preprint (which was not certified by peer review) is the author/funder, who has granted medRxiv a license to display the preprint in perpetuity.

It is made available under a CC-BY-NC-ND 4.0 International license .

133 Non-survivors had statistically significant higher TLC, NLR and CRP when compared to

134 the survivors $(\mathrm{P}<0.05)$. Hemoglobin, platelet count, lymphocyte count, neutrophil count,

135 PLR and SII were not significantly different between groups $(\mathrm{p}>0.05)$. Table 3 (d)

136 Prediction of disease severity, ICU admission and in-hospital mortality:

137 Table 4 shows the independent prediction ability of the studied biomarkers and the

138 optimal cut-off values calculated by the ROC analysis. As regards COVID-19 severity

139 prediction, CRP AUC was 0.707 with a cut off value of $12 \mathrm{mg} / \mathrm{L}$, sensitivity of $65.66 \%$

140 and specificity of $69.31 \%$, followed by NLR, SII and PLR with AUC of 0.700, 0.669 and

1410.640 , and cut-off values of 4.33, 1012.36 and 185, respectively. Regarding ICU

142 admission prediction, CRP AUC was 0.763 with a cut off value of $115 \mathrm{mg} / \mathrm{L}$, sensitivity

143 of $54.76 \%$ and specificity of $94.30 \%$, followed by NLR, SII and PLR with AUC of

$144 \quad 0.727,0.717$ and 0.580 , and cut-off values of 4.5, 668.57 and 300, respectively. For in-

145 hospital mortality prediction, CRP AUC was 0.812 with a cut off value of $141 \mathrm{mg} / \mathrm{L}$,

146 sensitivity of $70 \%$ and specificity of $95.56 \%$, followed by NLR with AUC of 0.751 and a

147 cut off value of 4.5. Figures 1-3

\section{Association with Disease Severity, ICU Admission and In-Hospital Mortality:}

149 To identify factors that may affect the disease severity, ICU admission or in-hospital

150 mortality, we obtained the odds ratios (OR) after conducting logistic regression analysis.

151 The multivariate analysis showed that SII (OR, 3.143; 95\% CI, 1.101-8.976; P $<0.05)$

152 was significantly positively associated with the disease severity, CRP (OR, 2.902; 95\%

153 CI, 1.342-6.273; P < 0.05) and NLR (OR, 2.662; 95\% CI, 1.072-6.611; P < 0.05) were

154 significantly positively associated with the need for ICU admission, and only CRP (OR, 
medRxiv preprint doi: https://doi.org/10.1101/2021.06.10.21258715; this version posted June 16, 2021. The copyright holder for this preprint (which was not certified by peer review) is the author/funder, who has granted medRxiv a license to display the preprint in perpetuity.

It is made available under a CC-BY-NC-ND 4.0 International license .

156 hospital mortality. Table 5

\section{DISCUSSION}

158 Since hyper-inflammatory state has been incriminated in the patho-physiology of

159 COVID-19, information about inflammation and the immune response of patients with 160 different disease severity should be continuously explored for predicting the progression 161 of the disease and improving the outcome of patients [1]. Complete blood counts are the 162 most easily performed tests in a time and cost-effective manner. Included in the CBC are 163 values that can be used as effective inflammatory biomarkers [4].

164 Neutrophils can be triggered by virus-related inflammatory factors to release large 165 amounts of reactive oxygen species and other cytotoxic mediators, which may dampen 166 the virus. Moreover, neutrophils are able to release neutrophil extracellular traps that help 167 in capturing and damaging different pathogens, including viruses [6].

168 On the other hand, severe cases of viral infection can result in lymphocyte exhaustion,

169 because viruses can directly attack and damage target cells; also, they can activate 170 immune cells to participate in the anti-viral process, resulting in severe lymphocyte 171 damage and apoptosis. Because systemic inflammation stimulates neutrophil production

172 and accelerates lymphocyte apoptosis, virus-triggered inflammation raises the NLR ratio $173[6]$.

174 Additionally, as platelets have an important role in the regulation of various 175 inflammatory processes, both the NLR and PLR indirectly reflect a patient's 176 inflammatory state [7]. In recent years, NLR and PLR have been validated as prognostic 
medRxiv preprint doi: https://doi.org/10.1101/2021.06.10.21258715; this version posted June 16, 2021. The copyright holder for this preprint (which was not certified by peer review) is the author/funder, who has granted medRxiv a license to display the preprint in perpetuity.

It is made available under a CC-BY-NC-ND 4.0 International license .

177 biomarkers in various disorders including cardiac conditions, solid tumors, sepsis,

178 pneumonia, and acute respiratory distress syndrome [8].

179 A recently proposed score is the SII, which is an index defining the instability in the

180 inflammatory response. SII has been proposed as a prognostic indicator in the follow-up

181 of patients with sepsis and in a number of tumors including small cell lung and

182 hepatocellular carcinomas [7].

183 The current study is aimed at exploring the role of NLR, PLR, and SII, in addition to the

184 CRP in predicting severity of the disease, the need for ICU admission and in-hospital 185 mortality in COVID-19 patients.

186 We found a significant relation between advancing patients' ages and the severity of the 187 disease as well as the rate of ICU admission and in-hospital mortality. However, these 188 could not be linked to a specific gender. Our findings were consistent with the studies of 189 Yang et al. and Fois et al. [4],[9], who reported significantly advanced age and non190 significant difference in gender in the more severe cases and the non-survivors, 191 respectively. However, our study was only partially consistent with Wang and colleagues 192 [10] who reported non-significant differences in age or gender with the progression of the 193 disease. Similar to the study of Yang et al. [4], we found the overall incidence of co194 morbidities (diabetes, hypertension, kidney dysfunction) to be significantly higher in the 195 more severe cases. However, partially contrary to the study of Fois et al. [9], who found 196 only a significant association between heart disease and COVID-19 mortality and a non197 significant association between disease mortality and the other co-morbidities including 198 smoking, diabetes, and kidney disease, we found that in-hospital disease mortality was 199 significantly higher in patients with diabetes, hypertension, kidney and heart diseases. 
medRxiv preprint doi: https://doi.org/10.1101/2021.06.10.21258715; this version posted June 16, 2021. The copyright holder for this preprint (which was not certified by peer review) is the author/funder, who has granted medRxiv a license to display the preprint in perpetuity.

It is made available under a CC-BY-NC-ND 4.0 International license .

200 Our study also showed a significant increase in NLR, PLR, SII, and CRP in the more 201 severe cases and in those who required ICU admission. However, only NLR and CRP 202 were significantly elevated in patients who died from the disease. This was in accordance 203 with the study of Yang and colleagues [4] who reported higher NLR, PLR and CRP in 204 the more severe cases of the disease. However, partially consistent with our study, Fois 205 and colleagues [9] reported significant elevation in NLR and SII in the non-survivor 206 group of the disease; they also reported that SII might specifically reflect the pulmonary 207 damage occurring in COVID-19 patients.

208 Our study revealed that the best cut-off points to predict disease severity and the need for 209 ICU admission were, CRP > 12mg/l \& > 115mg/l, NLR > $4.33 \&>4.5$, SII $>1012.36 \&$ $210>668.57$, and PLR > $185 \&>300$, respectively. Also, the best cut-off points to predict 211 in-hospital mortality were CRP > 145mg/l and NLR > 4.5. In view of our data, 4 of the 212188 included mild cases required ICU admission during their hospital stay. This resulted 213 in lowering the SII cut-off point of the need for ICU admission prediction compared to 214 that used to predict the disease severity. Furthermore, by multivariate regression analysis, 215 the SII was the best independent biomarker associated with disease severity; CRP and 216 NLR were the best independent predictors of the need for ICU admission; and only CRP 217 was significantly associated with the risk of in-hospital mortality. Yang and Co-workers 218 [4] found that both NLR and PLR were independent predictors of disease severity and 219 progression in their studied COVID-19 patients. Also, Fois and colleagues [9] found in 220 their study that the SII was the only independent biomarker to predict in-hospital 221 mortality of COVID-19 patients. 
medRxiv preprint doi: https://doi.org/10.1101/2021.06.10.21258715; this version posted June 16, 2021. The copyright holder for this preprint (which was not certified by peer review) is the author/funder, who has granted medRxiv a license to display the preprint in perpetuity.

It is made available under a CC-BY-NC-ND 4.0 International license .

222 One limitation in our study was its retrospective design that could not keep up with the

223 dynamic nature of the disease; more prospective studies with serial determination of

224 biomarkers' levels at different disease stages are still required for better definition of the

225 cut off points that could predict the progression of the disease. our study was its

226 retrospective design that could not keep up with the dynamic nature of the disease; more

227 prospective studies with serial determination of biomarkers' levels at different disease

228 stages are still required for better definition of the cut off points that could predict the

229 progression of the disease.

\section{CONCLUSIONS:}

231 Elevated CRP, SII, and NLR were found to be independent prognostic biomarkers that 232 could predict COVID-19 progression. The integration of CRP, SII, and NLR into

233 prognostic nomograms may lead to improved prediction. While CRP along with other

234 inflammatory markers like ESR, LDH, ferritin, and procalcitonin are frequently measured

235 in COVID-19 patients, SII and NLR can be easily calculated using a differential CBC

236 and are cost effective, especially for third world countries.

237 Abbreviations:

238 NLR, neutrophil to lymphocyte ratio; PLR, platelet to lymphocyte ratio; $R T-P C R$, reverse

239 transcription polymerase chain reaction; SARS-CoV-2, severe acute respiratory

240 syndrome coronavirus-2; SII, systemic immune-inflammation index.

241 Manuscript word count: 2515 words.

242 Abstract word count: 243 words 
medRxiv preprint doi: https://doi.org/10.1101/2021.06.10.21258715; this version posted June 16, 2021. The copyright holder for this preprint (which was not certified by peer review) is the author/funder, who has granted medRxiv a license to display the preprint in perpetuity. It is made available under a CC-BY-NC-ND 4.0 International license .

\section{Tables: 5}

\section{Figures: 3}

245 Funding sources: This research did not receive any specific grant from funding agencies 246 in the public, commercial, or not-for-profit sectors.

\section{Acknowledgement: None.}

248 Conflicts of interest: The authors declare that there is no conflict of interest regarding the 249 publication of this article.

250 Consent for publication: Not applicable.

251 Availability of data and materials: All data needed to support the current findings will be 252 available upon request.

253 Author contributions: Sara I. Taha: conceptualization, methodology, software; Sara F. 254 Samaan and Aalaa K. Shata: investigation, data collection. Shereen A. Baioumy 255 visualization, supervision. Mariam K. Youssef: writing- reviewing and editing, validation 256 and original draft preparation.

\section{REFERENCES}

258 [1] Zhu N, Zhang D, Wang W, Li X, Yang B, Song J, et al. China Novel Coronavirus

259 Investigating and Research Team. A Novel Coronavirus from Patients with Pneumonia in

260 China, 2019. N Engl J Med. 2020 Feb 20;382(8):727-733. doi:

261 10.1056/NEJMoa2001017. Epub 2020 Jan 24. PMID: 31978945; PMCID: PMC7092803.

262 [2] Chen N, Zhou M, Dong X, Qu J, Gong F, Han Y, et al. Epidemiological and clinical 263 characteristics of 99 cases of 2019 novel coronavirus pneumonia in Wuhan, China: a 
medRxiv preprint doi: https://doi.org/10.1101/2021.06.10.21258715; this version posted June 16, 2021. The copyright holder for this preprint (which was not certified by peer review) is the author/funder, who has granted medRxiv a license to display the preprint in perpetuity. It is made available under a CC-BY-NC-ND 4.0 International license .

264 descriptive study. Lancet. 2020 Feb 15;395(10223):507-513. doi: 10.1016/S0140-

265 6736(20)30211-7. Epub 2020 Jan 30. PMID: 32007143; PMCID: PMC7135076.

266 [3] Tan L, Wang Q, Zhang D, Ding J, Huang Q, Tang YQ, et al. Lymphopenia predicts 267 disease severity of COVID-19: a descriptive and predictive study. Signal Transduct 268 Target Ther. 2020 Mar 27;5(1):33. doi: 10.1038/s41392-020-0148-4. PMID: 32296069; 269 PMCID: PMC7100419.

270 [4] Yang AP, Liu JP, Tao WQ, Li HM. The diagnostic and predictive role of NLR, d271 NLR and PLR in COVID-19 patients. Int Immunopharmacol. 2020 Jul; 84:106504. doi: 272 10.1016/j.intimp.2020.106504. Epub 2020 Apr 13. PMID: 32304994; PMCID: 273 PMC7152924.

274 [5] Abdelfattah AB, Ahmed S, El-Zahapy H, Al Said A, Salem S, Tharwat A, et al. 275 Hospital response to COVID-19 a consensus: Report on Ain Shams University Hospital 276 Strategy. [published online ahead of print, June 12, 2020]. ScienceOpen. doi: 277 https://doi.org/10.14293/S2199-1006.1.SOR-.PPD4QZX.v1

278 [6] Feng X, Li S, Sun Q, Zhu J, Chen B, Xiong M, Cao G. Immune-Inflammatory 279 Parameters in COVID-19 Cases: A Systematic Review and Meta-Analysis. Front Med 280 (Lausanne). 2020 Jun 9;7:301. doi: 10.3389/fmed.2020.00301. PMID: 32582743; 281 PMCID: PMC7295898.

282 [7] Usul E, Şan İ, Bekgöz B, Şahin A. Role of hematological parameters in COVID-19 283 patients in the emergency room. Biomark Med. 2020 Sep;14(13):1207-1215. doi: 284 10.2217/bmm-2020-0317. Epub 2020 Jul 21. PMID: 32692248; PMCID: PMC7372996. 
medRxiv preprint doi: https://doi.org/10.1101/2021.06.10.21258715; this version posted June 16, 2021. The copyright holder for this preprint (which was not certified by peer review) is the author/funder, who has granted medRxiv a license to display the preprint in perpetuity. It is made available under a CC-BY-NC-ND 4.0 International license.

285 [8] Chan AS, Rout A. Use of Neutrophil-to-Lymphocyte and Platelet-to-Lymphocyte 286 Ratios in COVID-19. J Clin Med Res. 2020 Jul;12(7):448-453. doi: 10.14740/jocmr4240. 287 Epub 2020 Jun 25. PMID: 32655740; PMCID: PMC7331861.

288 [9] Fois AG, Paliogiannis P, Scano V, Cau S, Babudieri S, Perra R, et al. The Systemic 289 Inflammation Index on Admission Predicts In-Hospital Mortality in COVID-19 Patients. 290 Molecules. 2020 Dec 4;25(23):5725. doi: 10.3390/molecules25235725. PMID: $29133291581 ;$ PMCID: PMC7731255.

292 [10] Wang C, Deng R, Gou L, Fu Z, Zhang X, Shao F, et al. Preliminary study to identify 293 severe from moderate cases of COVID-19 using combined hematology parameters. Ann 294 Transl Med. 2020 May;8(9):593. doi: 10.21037/atm-20-3391. PMID: 32566620; PMCID: $295 \quad$ PMC7290538 
medRxiv preprint doi: https://doi.org/10.1101/2021.06.10.21258715; this version posted June 16, 2021. The copyright holder for this preprint (which was not certified by peer review) is the author/funder, who has granted medRxiv a license to display the preprint in perpetuity.

It is made available under a CC-BY-NC-ND 4.0 International license.

296 Table 1: Comparisons of patient demographic and clinical characteristics according to COVID-

29719 severity, ICU admission and in-hospital mortality.

\begin{tabular}{|c|c|c|c|c|c|c|c|c|c|c|c|}
\hline \multicolumn{2}{|c|}{ Variable } & $\begin{array}{c}\text { (a) } \\
\text { Total } \\
(\mathbf{n}=\mathbf{4 2 5})\end{array}$ & \multicolumn{3}{|c|}{ (b)Severity } & \multicolumn{3}{|c|}{ (c)ICU admission } & \multicolumn{3}{|c|}{ (d) In-hospital mortality } \\
\hline Age & $\underset{\text { SD }}{\operatorname{Mean} \pm}$ & $\begin{array}{c}47.90 \pm \\
17.08\end{array}$ & $\begin{array}{c}40.84 \pm \\
15.65\end{array}$ & $\begin{array}{c}53.47 \pm \\
16.10\end{array}$ & $\leq \mathbf{0 . 0 0 1}$ & $\begin{array}{c}44.70 \pm \\
16.41\end{array}$ & $\begin{array}{l}56.83 \pm \\
15.75\end{array}$ & $\leq \mathbf{0 . 0 0 1}$ & $\begin{array}{c}46.61 \pm \\
16.90\end{array}$ & $\begin{array}{c}60.30 \pm \\
13.60\end{array}$ & $\leq \mathbf{0 . 0 0 1}$ \\
\hline \multirow{2}{*}{ Sex } & Female & $\begin{array}{c}227 \\
(53.4 \%)\end{array}$ & $\begin{array}{c}110 \\
(58.5 \%)\end{array}$ & $\begin{array}{c}117 \\
(49.4 \%)\end{array}$ & \multirow[t]{2}{*}{0.061} & $\begin{array}{c}174 \\
(55.6 \%)\end{array}$ & $\begin{array}{c}53 \\
(47.3 \%)\end{array}$ & \multirow[t]{2}{*}{0.132} & $\begin{array}{c}205 \\
(53.2 \%)\end{array}$ & $\begin{array}{c}22 \\
(55.0 \%)\end{array}$ & \multirow[t]{2}{*}{0.832} \\
\hline & Male & $\begin{array}{c}198 \\
(46.6 \%)\end{array}$ & $\begin{array}{c}78 \\
(41.5 \%)\end{array}$ & $\begin{array}{c}120 \\
(50.6 \%)\end{array}$ & & $\begin{array}{c}139 \\
(44.4 \%)\end{array}$ & $\begin{array}{c}59 \\
(52.7 \%)\end{array}$ & & $\begin{array}{c}180 \\
(46.8 \%)\end{array}$ & $\begin{array}{c}18 \\
(45.0 \%)\end{array}$ & \\
\hline Severity & Mild & $\begin{array}{c}188 \\
(44.2 \%)\end{array}$ & & & & $\begin{array}{c}184 \\
(58.8 \%)\end{array}$ & $\begin{array}{c}4 \\
(3.6 \%)\end{array}$ & $\leq \mathbf{0 . 0 0 1}$ & $\begin{array}{c}188 \\
(48.8 \%)\end{array}$ & $\begin{array}{c}0 \\
(0.0 \%)\end{array}$ & $\leq \mathbf{0 . 0 0 1}$ \\
\hline $\begin{array}{c}\text { Hospital } \\
\text { stay } \\
\text { (days) }\end{array}$ & Range & $0-51$ & $0-36$ & $1-51$ & $\leq \mathbf{0 . 0 0 1}$ & $0-51$ & $1-40$ & $\leq \mathbf{0 . 0 0 1}$ & $0-51$ & $1-29$ & 0.018 \\
\hline \multirow{2}{*}{ ICU } & Negative & $\begin{array}{c}313 \\
(73.6 \%) \\
\end{array}$ & $\begin{array}{c}184 \\
(97.9 \%) \\
\end{array}$ & $\begin{array}{c}129 \\
(54.4 \%) \\
\end{array}$ & \multirow{2}{*}{$\leq \mathbf{0 . 0 0 1}$} & & & & $\begin{array}{c}312 \\
(81.0 \%) \\
\end{array}$ & $\begin{array}{c}1 \\
(2.5 \%) \\
\end{array}$ & \multirow{2}{*}{$\leq \mathbf{0 . 0 0 1}$} \\
\hline & Positive & $\begin{array}{c}112 \\
(26.4 \%)\end{array}$ & $\begin{array}{c}4 \\
(2.1 \%)\end{array}$ & $\begin{array}{c}108 \\
(45.6 \%)\end{array}$ & & & & & $\begin{array}{c}73 \\
(19.0 \%)\end{array}$ & $\begin{array}{c}39 \\
(97.5 \%)\end{array}$ & \\
\hline \multirow{2}{*}{ Fate } & Discharged & $\begin{array}{c}385 \\
(90.6 \%)\end{array}$ & $\begin{array}{c}188 \\
(100 \%)\end{array}$ & $\begin{array}{c}197 \\
(83.1 \%)\end{array}$ & \multirow{2}{*}{$\leq 0.001$} & $\begin{array}{c}312 \\
(99.7 \%)\end{array}$ & $\begin{array}{c}73 \\
(65.2 \%)\end{array}$ & \multirow{2}{*}{$\leq \mathbf{0 . 0 0 1}$} & & & \\
\hline & Death & $\begin{array}{c}40 \\
(9.4 \%)\end{array}$ & $0(0.0 \%)$ & $40(16.9 \%)$ & & $1(0.3 \%)$ & $\begin{array}{c}39 \\
(34.8 \%)\end{array}$ & & & & \\
\hline
\end{tabular}


medRxiv preprint doi: https://doi.org/10.1101/2021.06.10.21258715; this version posted June 16, 2021. The copyright holder for this preprint (which was not certified by peer review) is the author/funder, who has granted medRxiv a license to display the preprint in perpetuity.

\section{It is made available under a CC-BY-NC-ND 4.0 International license .}

299 Table 2: Comparisons of patient comorbidities according to COVID-19 severity, ICU admission

300 and in-hospital mortality

\begin{tabular}{|c|c|c|c|c|c|c|c|c|c|c|}
\hline $\begin{array}{c}\text { Comorb } \\
\text { idity }\end{array}$ & $\begin{array}{c}(a) \\
\text { Total } \\
(n=425)\end{array}$ & $\begin{array}{c}\text { Mild } \\
(n=188)\end{array}$ & $\begin{array}{c}\text { Modera } \\
\text { te to } \\
\text { severe } \\
(\mathbf{n}= \\
\mathbf{2 3 7})\end{array}$ & P-value & $\begin{array}{l}\text { Non- } \\
\text { ICU } \\
(\mathbf{n}=\mathbf{3 1 3})\end{array}$ & $\underset{(n=112)}{\text { ICU }}$ & P-value & $\begin{array}{c}\text { Survivo } \\
\text { rs } \\
(n=385)\end{array}$ & $\begin{array}{l}\text { Non- } \\
\text { survivo } \\
\text { rs (n= } \\
40)\end{array}$ & tality \\
\hline COPD & $\begin{array}{c}78 \\
(18.4 \%)\end{array}$ & $\begin{array}{c}15 \\
(8.0 \%)\end{array}$ & $\begin{array}{c}63 \\
(26.6 \%)\end{array}$ & $\leq \mathbf{0 . 0 0 1}$ & $\begin{array}{c}43 \\
(13.7 \%)\end{array}$ & $\begin{array}{c}35 \\
(31.3 \%)\end{array}$ & $\leq 0.001$ & $\begin{array}{c}65 \\
(16.9 \%)\end{array}$ & $\begin{array}{c}13 \\
(32.5 \%)\end{array}$ & 0.015 \\
\hline DM & $\begin{array}{c}129 \\
(30.4 \%)\end{array}$ & $\begin{array}{c}22 \\
(11.7 \%)\end{array}$ & $\begin{array}{c}107 \\
(45.1 \%)\end{array}$ & $\leq \mathbf{0 . 0 0 1}$ & $\begin{array}{c}67 \\
(21.4 \%)\end{array}$ & $\begin{array}{c}62 \\
(55.4 \%)\end{array}$ & $\leq \mathbf{0 . 0 0 1}$ & $\begin{array}{c}102 \\
(26.5 \%)\end{array}$ & $\begin{array}{c}27 \\
(67.5 \%)\end{array}$ & $\leq \mathbf{0 . 0 0 1}$ \\
\hline HTN & $\begin{array}{c}145 \\
(34.1 \%)\end{array}$ & $\begin{array}{c}26 \\
(13.8 \%)\end{array}$ & $\begin{array}{c}119 \\
(50.2 \%)\end{array}$ & $\leq \mathbf{0 . 0 0 1}$ & $\begin{array}{c}80 \\
(25.6 \%)\end{array}$ & $\begin{array}{c}65 \\
(58.0 \%)\end{array}$ & $\leq 0.001$ & $\begin{array}{c}119 \\
(30.9 \%)\end{array}$ & $\begin{array}{c}26 \\
(65.0 \%)\end{array}$ & $\leq \mathbf{0 . 0 0 1}$ \\
\hline CLD & $\begin{array}{c}17 \\
(4.0 \%)\end{array}$ & $\begin{array}{c}0 \\
(0.0 \%)\end{array}$ & $\begin{array}{c}17 \\
(7.2 \%)\end{array}$ & $\leq \mathbf{0 . 0 0 1}$ & $\begin{array}{c}11 \\
(3.5 \%)\end{array}$ & $\begin{array}{c}6 \\
(5.4 \%)\end{array}$ & 0.393 & $\begin{array}{c}16 \\
(4.2 \%)\end{array}$ & $\begin{array}{c}1 \\
(2.5 \%)\end{array}$ & 0.611 \\
\hline CKD & $\begin{array}{c}27 \\
(6.4 \%)\end{array}$ & $\begin{array}{c}2 \\
(1.1 \%)\end{array}$ & $\begin{array}{c}25 \\
(10.5 \%)\end{array}$ & $\leq \mathbf{0 . 0 0 1}$ & $\begin{array}{c}13 \\
(4.2 \%)\end{array}$ & $\begin{array}{c}14 \\
(12.5 \%)\end{array}$ & 0.002 & $\begin{array}{c}20 \\
(5.2 \%)\end{array}$ & $\begin{array}{c}7 \\
(17.5 \%)\end{array}$ & 0.002 \\
\hline IHD & $\begin{array}{c}42 \\
(9.9 \%)\end{array}$ & $\begin{array}{c}1 \\
(0.5 \%)\end{array}$ & $\begin{array}{c}41 \\
(17.3 \%)\end{array}$ & $\leq 0.001$ & $\begin{array}{c}16 \\
(5.1 \%)\end{array}$ & $\begin{array}{c}26 \\
(23.2 \%)\end{array}$ & $\leq \mathbf{0 . 0 0 1}$ & $\begin{array}{c}32 \\
(8.3 \%)\end{array}$ & $\begin{array}{c}10 \\
(25.0 \%)\end{array}$ & 0.001 \\
\hline
\end{tabular}

COPD, chronic obstructive pulmonary disease; DM, diabetes mellitus; HTN, hypertension; CLD,

302 chronic liver disease; CKD, chronic kidney disease; IHD, ischemic heart disease. Statistical 303 significance set at 0.05 . 
medRxiv preprint doi: https://doi.org/10.1101/2021.06.10.21258715; this version posted June 16, 2021. The copyright holder for this preprint (which was not certified by peer review) is the author/funder, who has granted medRxiv a license to display the preprint in perpetuity. It is made available under a CC-BY-NC-ND 4.0 International license .

304 Table 3: Comparisons of patient laboratory findings according to COVID-19 severity, ICU

305 admission and in-hospital mortality

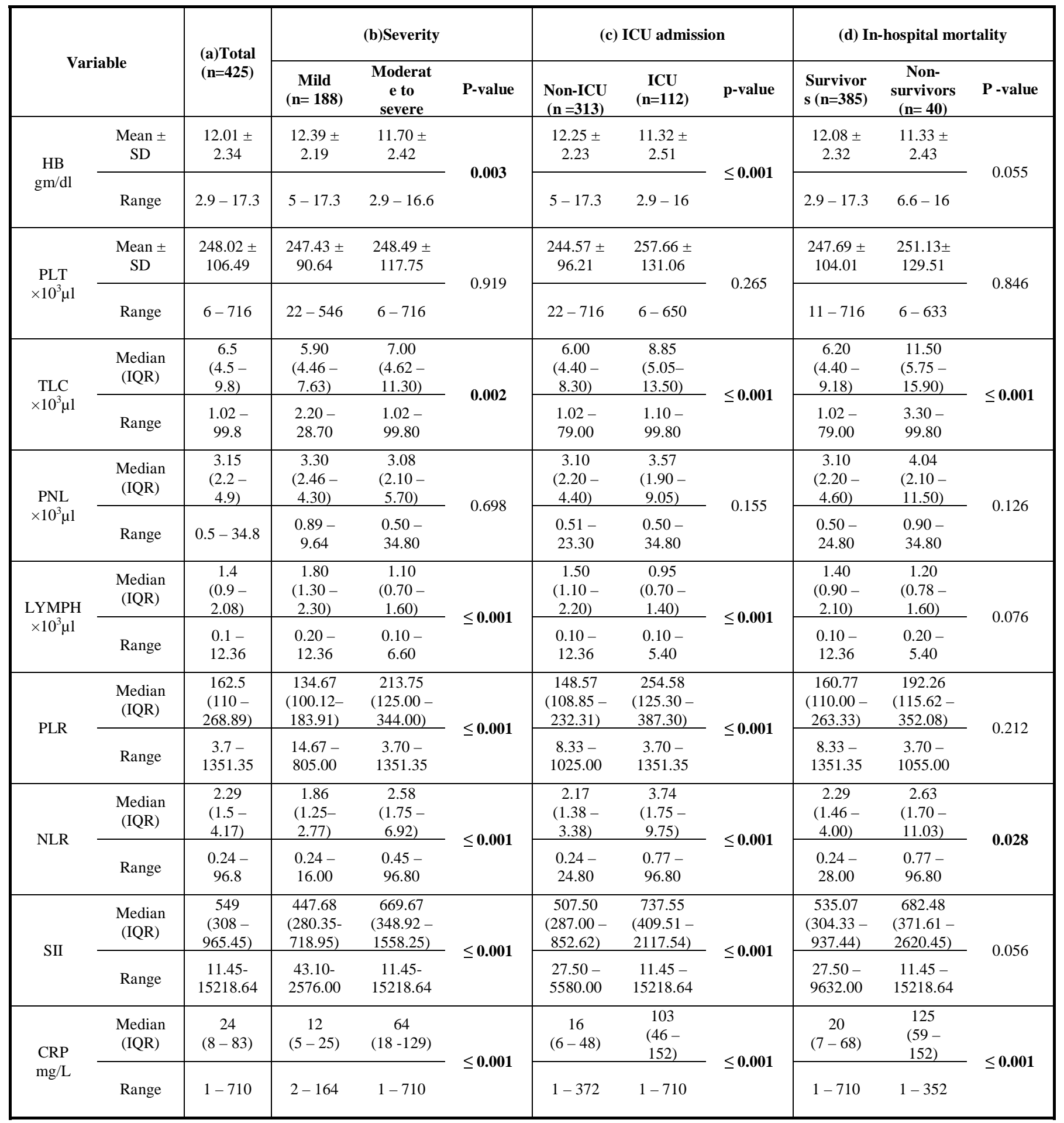

306 HB, hemoglobin; PLT, platelets; TLC, total leucocytic count; PNL; neutrophils; LYMPH, lymphocytes; 307 PLR, platelet to lymphocyte ratio; NLR, neutrophil to lymphocyte ratio; SII, systemic immune308 inflammation index (neutrophil*platelet to lymphocyte ratio); CRP, C-reactive protein. Statistical 309 significance set at 0.05 . 
medRxiv preprint doi: https://doi.org/10.1101/2021.06.10.21258715; this version posted June 16, 2021. The copyright holder for this preprint (which was not certified by peer review) is the author/funder, who has granted medRxiv a license to display the preprint in perpetuity.

It is made available under a CC-BY-NC-ND 4.0 International license .

310 Table 4: Recommended cut-off values for the prediction of COVID-19 severity, need for ICU

311 admission and in-hospital mortality.

\begin{tabular}{|c|c|c|c|c|c|c|}
\hline & $\mathbf{A U C}$ & Cut off & $\begin{array}{c}\text { Sensitivity } \\
\%\end{array}$ & $\begin{array}{c}\text { Specificity } \\
\%\end{array}$ & $\begin{array}{c}\text { PPV } \\
\%\end{array}$ & $\begin{array}{c}\text { NPV } \\
\%\end{array}$ \\
\hline $\begin{array}{c}\text { Disease severity } \\
\text { PLR } \\
\text { NLR } \\
\text { SII } \\
\text { CRP }(\mathbf{m g} / \mathrm{L}) \\
\end{array}$ & $\begin{array}{l}0.640 \\
0.700 \\
0.669 \\
0.707 \\
\end{array}$ & $\begin{array}{c}>185 \\
>4.33 \\
>1012.36 \\
>12\end{array}$ & $\begin{array}{l}51.52 \\
47.47 \\
46.46 \\
65.66 \\
\end{array}$ & $\begin{array}{l}80.20 \\
95.05 \\
93.07 \\
69.31 \\
\end{array}$ & $\begin{array}{l}71.8 \\
89.1 \\
86.8 \\
67.7 \\
\end{array}$ & $\begin{array}{l}62.8 \\
62.3 \\
63.9 \\
67.3 \\
\end{array}$ \\
\hline $\begin{array}{c}\text { ICU admission } \\
\text { PLR } \\
\text { NLR } \\
\text { SII } \\
\text { CRP }(\mathbf{m g} / \mathrm{L}) \\
\end{array}$ & $\begin{array}{l}0.580 \\
0.727 \\
0.717 \\
0.763 \\
\end{array}$ & $\begin{array}{l}>300 \\
>4.5 \\
>668.57 \\
>115 \\
\end{array}$ & $\begin{array}{l}38.10 \\
59.52 \\
71.43 \\
54.76 \\
\end{array}$ & $\begin{array}{l}89.87 \\
83.54 \\
63.92 \\
94.30 \\
\end{array}$ & $\begin{array}{l}50.0 \\
49.0 \\
34.5 \\
71.9 \\
\end{array}$ & $\begin{array}{l}84.5 \\
88.6 \\
89.4 \\
88.7 \\
\end{array}$ \\
\hline $\begin{array}{l}\text { In-hospital mortality } \\
\text { NLR } \\
\text { CRP (mg/L) }\end{array}$ & $\begin{array}{l}0.751 \\
0.812 \\
\end{array}$ & $\begin{array}{l}>4.5 \\
>141 \\
\end{array}$ & $\begin{array}{l}65.0 \\
70.0\end{array}$ & $\begin{array}{l}78.89 \\
95.56\end{array}$ & $\begin{array}{l}25.5 \\
63.6 \\
\end{array}$ & $\begin{array}{l}95.3 \\
96.6 \\
\end{array}$ \\
\hline
\end{tabular}

312 PLR, platelet to lymphocyte ratio; NLR, neutrophil to lymphocyte ratio; SII, systemic immune-

313 inflammation index (neutrophil*platelet to lymphocyte ratio); CRP, C-reactive protein; AUC, area

314 under the curve; NPV, negative predictive value; PPV, positive predictive value. 
medRxiv preprint doi: https://doi.org/10.1101/2021.06.10.21258715; this version posted June 16, 2021. The copyright holder for this preprint (which was not certified by peer review) is the author/funder, who has granted medRxiv a license to display the preprint in perpetuity.

It is made available under a CC-BY-NC-ND 4.0 International license .

315 Table 5: Logistic regression analysis for predictors of COVID-19 severity, ICU admission and in-

316 hospital mortality.

\begin{tabular}{|c|c|c|c|c|c|c|c|c|}
\hline \multirow{3}{*}{ Disease severity } & \multicolumn{4}{|c|}{ Uni-variate } & \multicolumn{4}{|c|}{ Multi-variate } \\
\hline & \multirow{2}{*}{ P-value } & \multicolumn{3}{|c|}{\begin{tabular}{|l|l|l} 
Odds ratio $95 \%$ C.I. for OR & \\
\end{tabular}} & \multirow{2}{*}{ P-value } & \multirow{2}{*}{$\begin{array}{c}\text { Odds ratio } \\
\text { (OR) }\end{array}$} & \multicolumn{2}{|c|}{ 95\% C.I. for OR } \\
\hline & & (OR) & Lower & Upper & & & Lower & Upper \\
\hline PLR & $\leq 0.001$ & 4.407 & 2.882 & 6.738 & 0.452 & 1.332 & 0.630 & 2.817 \\
\hline NLR & $\leq 0.001$ & 8.095 & 4.347 & 15.075 & 0.616 & 1.335 & 0.432 & 4.124 \\
\hline SII & $\leq 0.001$ & 7.808 & 4.191 & 14.547 & 0.032 & 3.143 & 1.101 & 8.976 \\
\hline CRP & $\leq 0.001$ & 6.017 & 3.893 & 9.300 & 0.166 & 1.533 & 0.837 & 2.808 \\
\hline \multicolumn{9}{|l|}{ ICU admission } \\
\hline PLR & $\leq 0.001$ & 4.757 & 2.880 & 7.857 & 0.069 & 2.271 & 0.939 & 5.491 \\
\hline NLR & $\leq 0.001$ & 5.111 & 3.132 & 8.342 & 0.035 & 2.662 & 1.072 & 6.611 \\
\hline SII & $\leq 0.001$ & 2.195 & 1.416 & 3.401 & 0.067 & 0.414 & 0.161 & 1.062 \\
\hline CRP & $\leq 0.001$ & 7.617 & 4.465 & 12.995 & 0.007 & 2.902 & 1.342 & 6.273 \\
\hline \multicolumn{9}{|l|}{ In-hospital mortality } \\
\hline NLR & 0.001 & 3.273 & 1.673 & 6.403 & 0.766 & 1.149 & 0.461 & 2.863 \\
\hline CRP & $\leq 0.001$ & 10.332 & 5.024 & 21.248 & 0.007 & 3.988 & 1.460 & 10.892 \\
\hline
\end{tabular}

317 PLR, platelet to lymphocyte ratio; NLR, neutrophil to lymphocyte ratio; SII, systemic immune-

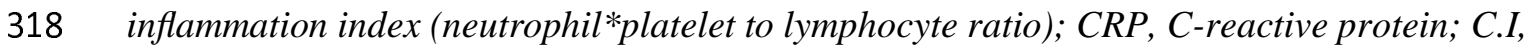

319 confidence interval. Statistical significance set at 0.05. 
medRxiv preprint doi: https://doi.org/10.1101/2021.06.10.21258715; this version posted June 16, 2021. The copyright holder for this preprint (which was not certified by peer review) is the author/funder, who has granted medRxiv a license to display the preprint in perpetuity.

\section{It is made available under a CC-BY-NC-ND 4.0 International license .}

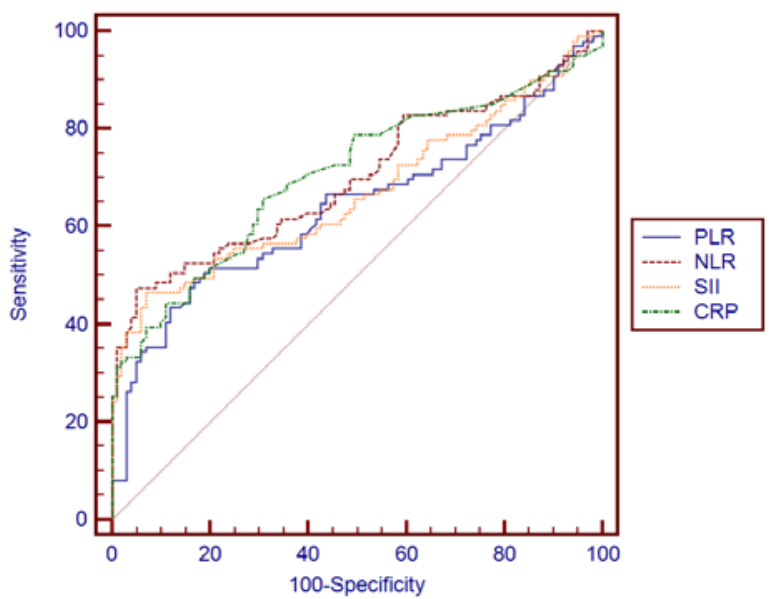

Figure1: Receiver-operating characteristic curve for prediction of disease severity

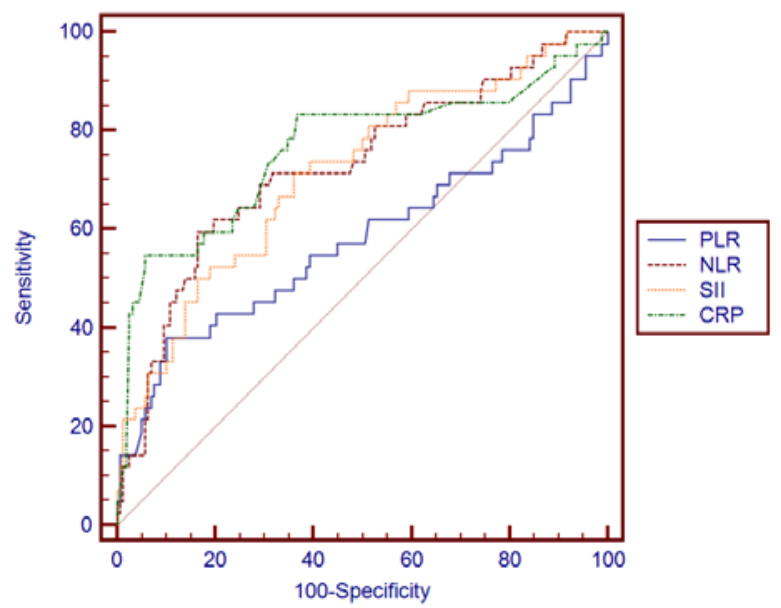

Figure 2: Receiver-operating characteristic curve for prediction of ICU admission

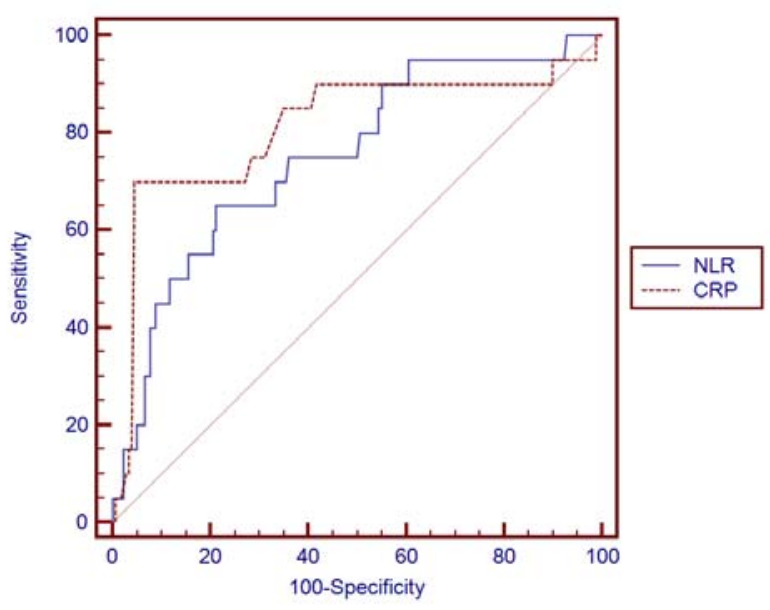

Figure 3: Receiver-operating characteristic curve for prediction of in-hospital mortality 